\title{
THE RELATIONSHIP BETWEEN EMOTIONAL INTELLIGENCE AND RECEPTIVE ENGLISH SKILLS OF TUNISIAN IT STUDENTS: A PRELIMINARY STUDY
}

\author{
${ }^{a}$ Mariem Ouaja, ${ }^{b}$ Utami Widiati, ${ }^{c}$ Yazid Basthomi, ${ }^{\text {d Khalil Jahbel }}$

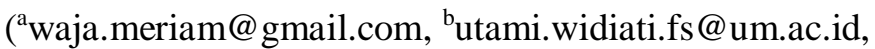 \\ cybasthomi@um.ac.id, denclavejung@gmail.com) \\ ${ }^{a}$ Université Centrale Privée de Tunis \\ 56 Rue de Syrie, Tunis 1002, Tunisia \\ ${ }^{b, c}$ Universitas Negeri Malang \\ Jalan Semarang 5 Malang, Indonesia \\ ${ }^{d}$ Azzaytuna University \\ Tarhuna, Libya
}

\begin{abstract}
This study aims at discovering the emotional intelligence and receptive English skills of Tunisian IT students, studying the relationship between the two variables, and determining the best predictors of receptive English skills among the emotional intelligence categories. It involved 31 students of the Higher Institute of Technology and Communications Science of Tunis. Data were collected by administering an English proficiency test (TOEIC) and distributing an emotional intelligence inventory (Bar-On EI Inventory) to the students. The results of statistical analyses revealed that (1) the emotional intelligence and receptive English skills of the students were of average levels; (2) there was a significant positive correlation between the students' emotional intelligence and their receptive English skills; and (3) interpersonal and stress management categories of emotional intelligence were the variables that had the highest correlation with receptive English skills. It was also found that, in learning English language, the Tunisian IT students were driven and motivated by their goals and ambitions. In addition, their optimism, linguistic setting, and Tunisian culture strongly influence their receptive English skill.
\end{abstract}

Keywords: emotional intelligence, IT students, receptive English skills, Tunisia

DOI: http://dx.doi.org/10.15639/teflinjournal.v31i2/230-258 
Emotional intelligence (EI) has been influential in educational psychology in general and in second and foreign language learning and teaching in particular since its inception in 1990s. The term emotional intelligence (EI) was introduced as the capacity to generate and control one's own and others' emotions, to differentiate among them, and to use them to handle one's thinking and actions (Salovey \& Mayer, 1990, p. 189). Since then, EI has had many varied and fundamentally different definitions. It has also been defined as the individuals' ability to realize their own and other persons' emotions, to distinguish among various kinds of emotions, to organize these feelings precisely, and to control and regulate their own thinking and behavior (Bar-On, 1997a; Goleman, 1995). Thus, EI is an intermixture of complementary emotional and social capacities and competences that demonstrate how efficiently an individual recognizes and expresses his or her emotions, recognizes emotions of other people, and socially interacts with them, and deals with life challenges and difficulties.

Goleman (1995) argues that EI is not an alternative to cognitive intelligence, but rather an addition to it, which makes it a distinctive form of intelligence. He also suggests that EI generates accomplishment in diverse domains such as personality, academic situations, and employment. However, Goleman's statements about EI's contribution in different domains were not yet adequately supported by empirical evidences. According to Bar-On and Parker (2000), EI is an intermixture of emotional, personal, and interpersonal skills that affect one's overall capacity to confront life circumstances and difficulties, generally termed as affective competences. In other words, many educational institutions seem to have incorporated learning along with affective programs into their curriculum regardless of the lack of empirical evidence to support Goleman's claims.

Later on, researchers and experts started to examine EI and achievement (Barisonek, 2005; Dağl1, 2006; Evenson, 2007; Parker et al, 2004; Walker, 2006; Y1lmaz, 2007). It has been agreed upon that emotions and affective factors have a fundamental role in students' personality and academic life, especially in foreign language learning. In this concern, Krashen (1981) states, even before the inception of EI, it was understood that affective factors could influence learners negatively or positively. For instance, a high level of anxiety and a low level of motivation may negatively affect an individual's learning process. On the other hand, a low level of anxiety and a high level of motivation positively influence the learning process. Elias and Arnold (2006) 
also found that EI skills help learners behave in social classroom settings in a flexible way and thus achieve better. In a second language learning context, Lightbown and Spada (2010) highlight that unfavorable emotional conditions block students from acquiring language input efficiently. This supports the idea that EI skills should also be crucial in foreign language learning (Reimer, cited in Motallebzadeh, 2009).

Regarding achievement, a lot of researchers have explored further the relationship between EI and academic success (Afshar et al., 2016.; Dağl1, 2006; Evenson, 2007; Hasanzadeh \& Shahmohamadi, 2011; Li, 2019; Parker et al., 2004; Walker, 2006). The findings displayed a close relationship between several dimensions of EI and academic success. Much research has demonstrated that there is a significant relationship between emotional and social skills and success in different domains, including efficient teaching and learning, interpersonal relationships, academic performance, and English language achievment (Brackett \& Salovey, 2004; Hassan, 2015; Sutten \& Wheatley, 2003). However, these findings do not match those of similar research studies (Barisonek, 2005; Fahim \& Pishgadam, 2007; Y1lmaz, 2007) reporting that there is not any relationship between EI and academic success.

In the field of English language teaching, EI is a relatively new concept; therefore, only few research studies have been conducted regarding its impact on second/foreign language learning. A number of researchers have then suggested that more investigations should be carried out to determine the impact of EI on language learning (Ghosn, 2001; Mayer et al., 2000). As Chao (2003) further stated that attention should be given to the concept of EI in foreign language learning because its skills help learners improve their abilities to learn a language. EI plays an important role in all cognitive and psychological features of foreign language learning (Martin, 2010). Studies have showed that the higher the level of EI is, the lower the level of anxiety is (see, e.g. Dewaele, 2013; Farsian et al., 2015).

In terms of the relationship between EI and language skills development, several studies have also been done. Oz et al. (2015), for example, investigated the possible relationship between perceptions of EI and attitudes towards foreign language. The study revealed a statistically positive correlation between components of EI and attitudes towards foreign language learning. Motallebzadeh (2009) found that there is a strong relationship between EI and reading as well as between EI and structural ability. The researcher also claimed that EI significantly contributed to the improvement of reading and 
structural skills. In a similar study done by Firdaus (2017), the result showed that there was a postive significant correlation between students' emotional intelligence and reading comprehension. Moreover, in studying the impacts of enhancing EI on the development of reading skill, Ebrahimi et al. (2018) assumed that developing EQ can cause progress in language in general. After one year, the progress in Reading Skill along with EQ was observed. In addition, a study carried out by Pisghadam (2009a) examined the effect of both emotional and verbal intelligences on students' English language skills. The results revealed that concerning productive skills, EI was more significant than verbal intelligence; however, it was not certain yet whether it is more significant than verbal intelligence in receptive skills. The researcher also shed light on the importance of considering the emotional conditions of English learners, as EI strongly affects their English language skills. Pishghadam (2009b), as well, studied the relationship between every sub-category of EI and English language skill. Intrapersonal category correlated with the listening and speaking skills; interpersonal category correlated with the speaking skill; adaptability correlated with the reading and writing skills; stress management correlated with the reading, listening, and writing skills; and general mood correlated with the reading and speaking skills. However, according to a study carried out by Hasanzadeh and Shahmohamadi (2011), there is no relationship between EI and English test performance. Through a study about EI and its predictors of EFL learners' success based on the learners' scores on an English final achievement test, they also found that intrapersonal and interpersonal skills predicted language success.

A century of research on intelligence in general, and cognitive intelligence and performance in particular, has overshadowed the effectiveness of other non-cognitive factors such as the emotional/affective factors which significantly contribute to one's success in different learning contexts, including the EFL context. Although there have been a number of studies on EI and language learning (e.g., Martin, 2010; Motallebzadeh, 2009; Shakib \& Barani, 2011), few have been conducted in an EFL context. The majority of the research studies conducted imply that EI has a crucial role in language learning. However, more recent studies revealed that there is no correlation or a negative one between EI and language proficiency (e.g., Zarafshan \& Ardeshiri, 2012). In other words, the findings of several studies on the relationship between EI and language proficiency seem contradictory, and thus needs are felt for more studies to be conducted in this regard. Such mixed 
results have triggered the proposal of this study, particularly because no similar study has ever been conducted in the Tunisian context. Moreover, since most studies are conducted in monolingual environments, it is an opportunity to discover whether previous research results can also be considered in the Tunisian context as Tunisia has been regarded to have varied and complex linguistic settings. The common tongue is a mixture of many different languages, mostly Arabic, French, and Tamazight (Berber language). However, the official language of the state is Arabic, and of higher education and scientific studies is French. From the elementary school until the high school, Tunisian students use a combination of French and Arabic in different academic subjects. In undergraduate or higher education establishments, the French language becomes the main language of instruction in most fields. As for English, it is taught as a foreign language starting from the $10^{\text {th }}$ grade of elementary school.

Furthermore, the growing demand for English in Tunisia has been motivated by a desire to access scientific and technological information directly from original sources, rather than through French which has come to be seen as a handicap in the quest for faster modernization, development, and integration in the global community (Daoud, 2001). Therefore, English is regarded as very important for those who consider scientific research or seek more opportunities in the job market. This has led curriculum designers and experts as well as students themselves to try hard to integrate English language in the new system which is believed to have improved IT students' receptive English skills. In studying the perceived value of English language, Melliti (2008) found that Tunisian science students are aware of the importance of English, which made them suggest innovative measures to be taken to promote the learning of it. In this regard, the present study aims at exploring and understanding the relationship between EI and receptive English skills of Tunisian IT students, suggesting new measures in English teaching, and finding out whether the categories of EI that predict language skills are the same among all populations. Accordingly, the present study attemps to discover: (1) How are the EI and receptive English skills of Tunisian IT students? (2) Do Tunisian IT students with high EI get high scores in receptive English skills test? (3) What are the EI components that best predict the receptive English skills of Tunisian IT students? 
Ouaja, Widiati, Basthomi, \& Jahbel, Emotional Intelligence and English Skills 235

\section{METHOD}

This study involved undergraduate students of IT department in a university in Tunis. The students were in their $5^{\text {th }}$ semester of the 2019/2020 academic year. The IT department offers a 3-year degree program (5 semesters) leading to a bachelor degree in Telecommunications. The department aims at equipping students with up-to-date knowledge and practical skills in computer, network security, and telecommunications. At the end of the program, in order to obtain the degree, students are required to pass an international English proficiency test (TOEIC) requiring inter alia receptive English skills.English for communication (or specific English) is taught as a compulsory subject in the transversal unit for five semesters and with 2 credits in every semester. Considering that all the program courses are taught in French, IT students do not get enough English input despite the fact that English skills for communication purposes are considered important for further studies, research, or job opportunities in this field.

In total, there were 31 IT students willing to participate in the study, 16 males and 15 females. The age of the participants ranged from 20 to 23 years. Although all the participants are Tunisians, they have different language backgrounds as they come from different regions of Tunisia.

Two fundamental instruments were used in this study. The first one was an EI Inventory invented by Bar-On (1997b) and adapted and implemented by Karaman (2012) to measure the students' EI level. The EI inventory covers aspects of Intrapersonal Competence (Emotional self-awareness, Assertiveness, Self-regard, Self-actualization, Independence), Interpersonal Competence (Empathy, Interpersonal-relationship, Social Responsibility), Adaptability (Problem Solving, Reality Testing, Flexibility), Stress Management (Stress Tolerance, Impulse Control), and General Mood (Optimism, Happiness). Karaman's adapted version is composed of 88 items instead of 133 items. There were15 items that did not belong to any sub-category as they only determined people's tendency to complete the questionnaire and other repetitive items. The second one was TOEIC (Test of English for International Communication) to measure the students' proficiency level; however, as adumbrated earlier, the focus here was on the receptive English skills.

The Bar-On EQ-I consists of 5 categories and 15 sub-categories that describe the emotional social intelligences of a person rather than cognitive intelligence or personality. Thus, this implies that the Bar-On model is a valid 
approach for Tunisian students in that it illustrates the main features of emotional-social intelligences rather than other psychological and cultural aspects. Regarding the reliability of the questionnaire, the Cronbach's alpha was calculated and turned to be relatively high, 0.84. As for the second instrument, an adapted version of TOEIC exam administrated by the institute where the students learnt was used. According to the curriculum, the students' English proficiency is to be measured through the TOEIC. TOEIC test results demonstrate the proficiency of individuals in terms of the receptive English language skills (listening and reading). The total score is a combination of the two scaled scores of listening and reading together. There are 100 questions in each of the listening and reading sections, with the duration of 45 minutes for listening and 75 minutes for reading. Each correct answer is awarded one mark. Scores out of 100 are converted to the TOEIC scale. The final score is calculated by summing both scores of reading and listening to get a score that varies from 0 to 990 .

The data collection was conducted in two sessions. In the first session, the proficiency test which lasted for 120 minutes was carried out. The test was scored by the English teachers of the institute as they administrated the test and this was in accord with the requirements of the TOEIC testing system. In the second session, the participants responded to the Bar-On EQ-I questionnaire within 60 minutes.

Descriptive analysis, correlation, and Stepwise Multiple Regression were utilized to answer the three research questions. The descriptive statistics was run to measure the levels of EI and the receptive English skills of Tunisian IT students. An array of criteria was set to describe the EI mean scores of the participants as Low EI, Average EI, or High EI. According to the test mean scores to describe the receptive English skills of the participants was described as Very Low, Low, Average, High, or Very High. Pearson correlation was used to measure the degree of relationship between the two non-manipulated variables (Creswell, 2012). Furthermore, Stepwise Regression Analysis was employed to see which EI components and sub-components are the best predictors of receptive English skills since Multiple Regression is a statistical method that removes independent variables which are unrelated to the dependent variable in order to reach the best predictors. 
Ouaja, Widiati, Basthomi, \& Jahbel, Emotional Intelligence and English Skills 237

\section{FINDINGS AND DISCUSSION}

\section{Levels of EI and Receptive English Skills}

The first research question of this study concerns the levels of EI and receptive English skills of the Tunisian IT students. The Bar-On E.Q-I implemented by Karaman was adopted to measure the EI (see appendix). Table 1 shows that the students' EI overall mean is of average level (3.476). The highest score is 4.171, which shows high level of EI, whereas the lowest score is 2.924, which is of an average level. Such data show that the EI of Tunisian IT students vary from average to high. As for the categories, the highest score is of adaptability (4.610) and the lowest is of stress management (2.131). Interpersonal category has the highest mean (3.726), whereas the lowest mean score is that of stress management (3.118). Thus, it can be said that interpersonal and general mood categories of Tunisian IT students are more significant than intrapersonal, adaptability, and stress management categories.

Table 1. Descriptive Statistics of EI of Tunisian IT Students

\begin{tabular}{lccccc}
\hline & N & Mean & Min & Max & SD \\
\hline EI & 31 & 3.476 & 2.924 & 4.171 & 0.293 \\
\hline Intrapersonal & 31 & 3.451 & 2.708 & 4.491 & 0.396 \\
\hline Interpersonal & 31 & 3.726 & 2.837 & 4.354 & 0.400 \\
\hline Adaptability & 31 & 3.407 & 2.876 & 4.610 & 0.351 \\
\hline Stress management & 31 & 3.118 & 2.131 & 3.929 & 0.404 \\
\hline General mood & 31 & 3.677 & 2.929 & 4.357 & 0.336 \\
\hline
\end{tabular}

In this study, the EI questionnaire was used for the first time in the Tunisian context. There have been a few research studies examining different psychological aspects of Tunisian students, but little previous research considered a full analysis of the EI of Tunisian IT students' population. In studying EI and English test proficiency, Karaman (2012) who also used BarOn EI inventory to measure the EI of Turkish IT students found that despite the high EI scores, all participants had low scores in stress management category. If the score is high, the categories scores that compose it are supposed to be high as well, or vice versa. However, this assumption was not true for most categories. Although the overall score of Emotional Intelligence was average, the scores of general mood and interpersonal categories were high. 
Next, the TOEIC exam was administered in order to measure the students' proficiency, which includes the receptive English skills of listening and reading. As shown in Table 2, the students' scores vary from low (390) to high (920). As for the overall mean score, it is found to be average (707.581).

Table 2. Descriptive Statistics of Receptive English Skills of Tunisian IT Students

\begin{tabular}{lccccc}
\hline & N & Mean & Min & Max & SD \\
\hline $\begin{array}{l}\text { Receptive English } \\
\text { skills test }\end{array}$ & 31 & 707.581 & 390 & 920 & 149.085 \\
\hline
\end{tabular}

The students' scores in the TOEIC, which were generally on an average level, can be considered quite good in the context of Tunisia because the main language of instruction in higher scientific and technological fields in the country is the French. However, these findings cannot be generalized since this study is focused on measuring the students' receptive skills, and the sample is considered small and specific compared to the whole population of Tunisian students. As a comparison, according to EF English Proficiency Index 2019 report, which studied the acquisition of English skills for secondary and tertiary students, the score of English proficiency in Tunisian students is of low level (Education First EPI, 2019).

\section{The Relationship between EI and Receptive English Skills}

The second research question studied the relationship between the EI and the receptive English skills of the Tunisian IT students. Table 3 presents the correlation between the students' EI and receptive English skills as well as the correlations between each category of the EI and the receptive English skills. The results of Pearson correlations include the error (R2) for a better and more accurate correlation coefficients at the significance level of $\alpha=0.05$.

As presented in Table 3, all correlations found are positive, and EI strongly correlates with receptive English skills $(\mathrm{R} 2=0.7984 ; \mathrm{p}=8.168 \mathrm{e}-12)$. This finding indicates the working research hypothesis of the relationship between EI and receptive English skills. Moreover, all the categories of EI also correlate with receptive English skills with different levels. There is a moderate correlation between stress management and receptive English skills (R2= $0.3206 ; \mathrm{p}=0.003651$ ), whereas receptive English skills has a strong relationship with general $\operatorname{mood}(\mathrm{R} 2=0.6004 ; \mathrm{p}=0.000003505)$. 
Ouaja, Widiati, Basthomi, \& Jahbel, Emotional Intelligence and English Skills 239

Table 3. Correlations of EI and Receptive English Skills (RES) of Tunisian IT Students

\begin{tabular}{lcl}
\hline & Pearson (Adjusted R $\mathbf{R}^{2}$ ) & Sig (p-value) \\
\hline EI and EP & 0.7984 & $8.168 \mathrm{e}-12$ \\
\hline Intrapersonal and EP & 0.4664 & 0.001227 \\
\hline Interpersonal and EP & 0.5280 & 0.00007806 \\
\hline Adaptability and EP & 0.4781 & 0.0002696 \\
\hline Stress management and EP & 0.3206 & 0.003651 \\
\hline General mood and EP & 0.6004 & 0.000003505 \\
\hline
\end{tabular}

The above results explain the fact that the participants' overall scores in both EI and receptive English skills were of average levels. The data also show that some students had low scores in receptive English skills test, whereas the minimum scores in EI were average. The strong relationship between these two variables supports the early claims of Goleman (2006) about the benefits of EI to students, schools, and academic achievements. These findings are in line with several previous studies revealing that EI correlated with language success, such as the one in the Iranian context by Pishghadam (2009b), but contradict other studies that showed no correlation or a negative one between EI and language proficiency (e.g., Zarafshan \& Ardeshiri, 2012).

\section{Receptive English Skills Predictors}

In order to determine the best predictors of receptive English skills among the EI categories, Stepwise multiple regression method was employed. The regression method presented in Table 4 reveals the best predictors of receptive English skills in this study. Interpersonal and Stress Management categories are the best variables that can predict receptive English skills, whereas Intrapersonal, Adaptability, and General Mood are eliminated.

These findings can be explained by the fact that language is a means of communication, and Interpersonal category consists of skills and behaviors that a person uses to interact and communicate with others in order to have a meaningful and comfortable interaction. Therefore, some researchers and experts predict that people who have high interpersonal skills or willingness to communicate are better in using and mastering the four language skills. Plonsky and Brown (2015) state that interaction is the basis of L2 learning, through which learners are engaged both in enhancing their own communicative abilities and in socially constructing their identities through 
collaboration and negotiation. Research has also found that communication affects strongly second or foreign language learning (e.g., Noroozi, 2017).

\section{Table 4. Receptive English Skills Predictors among Categories}

\begin{tabular}{lccccc}
\hline & Estimate & S.Error & t value & $\operatorname{Pr}(>|\mathbf{t}|)$ & \\
\hline (Intercept) & -991.74 & 131.62 & -7.535 & 0.0000000688 & $* * *$ \\
\hline Interpersonal & 185.26 & 36.18 & 5.121 & 0.0000272894 & $* * *$ \\
\hline $\begin{array}{l}\text { Stress } \\
\text { management }\end{array}$ & 101.13 & 36.90 & 2.741 & 0.0112 & $*$ \\
\hline Sig. Codes: 0 '***' $0.001^{\prime * * '} 0.01^{\prime *} 0.05$ '.' $0.1^{\prime \prime}$ ' 1 & & \\
\hline
\end{tabular}

Stress Management category also has an important role in language proficiency. In second language acquisition theories, stress management is considered a main factor contributing to not only the speed of the learning process but also the quality of learning. It is also claimed that managing the stress is likely to facilitate language learning and that mastering the different language skills contributes to relieving the stress and anxiety of the learner. Therefore, stress management and receptive English skills have a two-way relationship. Related to this, self-confidence is believed to be highly related to language development. Interpersonal skills and stress management under this study are two main measures of self-confidence. In almost all studies conducted to determine the personality characteristics associated with successful language learning, researchers have concluded that lower anxiety level and a tendency to be out-going were connected with successful language acquisition. Shao et al. (2013) and Yu et al. (2015) also found that EI is directly linked to foreign language anxiety and L2 achievement in a negative and positive way respectively.

\section{Table 5. Receptive English Skills Predictors among Sub-categories}

\begin{tabular}{lccccc}
\hline & Estimate & S.Error & $\mathbf{t}$ value & $\operatorname{Pr}(>|\mathbf{t}|)$ & \\
\hline (Intercept) & -991.74 & 131.62 & -7.535 & 0.0000000688 & $* * *$ \\
\hline Intrapersonal_SA & 155.47 & 59.18 & 2.627 & 0.0148 & $*$ \\
\hline Interpersonal_IR & 115.56 & 46.35 & 2.493 & 0.0193 & $*$ \\
\hline Adaptability_F & 95.57 & 43.17 & 2.214 & 0.035828 & $*$ \\
\hline Adaptability_PS & 176.68 & 46.03 & 3.838 & 0.000712 & $* * *$ \\
\hline Stress & 156.46 & 47.77 & 3.275 & 0.0029 & $* *$ \\
\hline
\end{tabular}


Ouaja, Widiati, Basthomi, \& Jahbel, Emotional Intelligence and English Skills 241

\begin{tabular}{lccccc}
\hline & Estimate & S.Error & t value & $\operatorname{Pr}(>|\mathbf{t}|)$ & \\
\hline Management_ST & & & & & \\
\hline General Mood_H & 189.12 & 41.45 & 4.562 & 0.0000988 & $* * *$ \\
\hline General Mood_O & 164.85 & 36.08 & 4.568 & 0.0000971 & $* * *$ \\
\hline
\end{tabular}

Since all the categories of EI correlate with receptive English skills, the Stepwise Multiple Regression appears reliable to find out the best predictors within each category as shown in Table 5. Self-actualization (SA) is found to be the best predictor among the intrapersonal sub-categories, whereas all the other sub-categories are eliminated from the model. Self-actualization is defined as "the desire for self-fulfillment, namely the tendency for individuals to become actualized in what they are potentially. This tendency might be phrased as the desire to become more and more what one is, to become everything that one is capable of becoming" (Maslow, 1943, p. 383). In other words, self-actualization illustrates the progress of an individual in the achievement of a higher goal or need. Self-actualization as the predictor of receptive English skills can be related to Tunisian IT students by the fact that English language is needed in order to grow bigger and to obtain better opportunities. Thus, their receptive English skills are strongly linked to their self-actualization and determination to fulfill their goals.

Additionally, Interpersonal Relationship (IR) is the best predictor of receptive English skills. Empathy and social responsibility are eliminated from the model. Since language is based on communication, interpersonal relationship is a major factor in language proficiency. Countless theories emphasized that communication and interaction are crucial for language learning (Rost \& Candlin, 2013). Among these theories is the communicative approach which is based on the assumption that having real meaningful communication is the key to learning a language successfully (Oxford et al., 1989).

Interpersonal relationship in the context of Tunisian IT students tend to be related to cultural and linguistic setting aspects. Tunisia is considered a multilingual society where there is a mixture of different languages, and there are different language environments. A recent study claimed that multilingual people were found to have better interpretation and communication skills, which they presumed was due to the fact that a multilingual must continually interpret the intentions and perspectives of others (Fan et al., 2015). Some studies also found that people who speak more than one language tend to be 
more open-minded and culturally confident and find it easier to communicate and work with people from different backgrounds and cultures (Dewaele, 2015, 2019; Dewaele \& Wei, 2012). These findings might relate to the idea that Tunisians in general, and Tunisian students in particular, tend to be openminded, friendly, and curious about other cultures and people (Arfaoui, 2017). Moreover, the language of instruction in higher education is the French language, so the Tunisian IT students are used to using other languages than their native language in classroom communications and presentations. These characteristics and aspects build more self-confidence in interacting using the English language whether in formal or natural environments such as through social gathering, media, or in the classroom. As a result, their interpersonal relationships might have contributed to boosting their learning process.

Regarding adaptability category, problem solving is the best predictor of receptive English skills. Flexibility (F) also predicts receptive English skills, whereas reality testing is eliminated. Problem solving (PS) skill is the capacity to identify problems in one's life and find adequate solution to address them. Many researchers and language experts claim that problem solving is considerably related to language learning process which results in language proficiency. Individuals who are problem oriented are found to be more aware of their learning process as they can identify problems they face in learning a language, and thus find and employ the appropriate strategy to address that problem. As for flexibility, it mainly has to do with the ability to easily and quickly adapt to changing situations and face different types of challenges. This can be related to receptive English skills in a way that learners can easily adjust to and deal with different and challenging linguistic patterns and learning styles. In addition, many researchers have found that the bilingual brain is more flexible and adaptable (Buchweitz \& Prat, 2013). The nature of the educational system of Tunisian IT students improves their problem solving and flexibility skills since it is highly based on finding solution to different issues and coping with the rapid change in technology. The various assessments and testing forms are likely to play a role in boosting the flexibility of the students. Furthermore, bilingualism and the use of two different languages actively make students more flexible and relaxed in switching codes or facing different situations. Mixing Tunisian Arabic and French ranges from simple code-switching involving the use of French words in Arabic discourse to extensive code-mixing where speech may become predominantly French. French interacts with modern standard Arabic and educated Arabic in more 
subtle ways, thus influencing modern standard Arabic syntax and word choice, mostly through a process of translation, and going as far as rhetorical organization (Daoud, 1991). Thus, Tunisian IT students tend to employ these skills in addressing problems and facing different challenges related to English language learning which help them improve their receptive English skills.

Among stress management sub-categories, stress tolerance (ST) is the best predictor of receptive English skills. The impulse control sub-category is eliminated from the model. Stress tolerance is the capacity to endure pressure and anxiety and to function effectively and with minimal anxiety under conditions of stress. Lack of anxiety is believed to be an important factor in language proficiency. Therefore, the ability to control, manage, and reduce the level of stress deeply contributes to improving and facilitating the learning process. Stress tolerance can improve learners' self-regulation which allows individuals to set goals as well as to control and monitor their behavior and cognition. Moreover, in studying the relationship between EI and foreign language anxiety, many researchers such as Chao (2003), Rouhani (2008), Şakrak (2009), and Yerli (2009) found that there is a significant relationship between EI and foreign language anxiety. In the Tunisian IT students' context, the findings show that the participants had overall average stress management skills which can explain their average receptive English skills. According to Eysenck et al. (2007), students suffering from stress and anxiety have decreased cognitive functioning, such as a reduced memory capacity and problems with processing information. Furthermore, most of participants agreed that it is difficult for them to control their anxiety and stress. This can be explained by the fact that the interference of their native language (Tunisian Arabic), their first language (formal Arabic) and their second language (French language), as well as the lack of exposure to English language environment create some kind of confusion when learning a foreign language, which increases their anxiety and fear of not properly learning English language. Moreover, the hectic and demanding educational system along with the insufficient time available and given to learn English hinder their capacity to manage and cope with stress knowing that English is an essential step in fulfilling their goals.

Both happiness $(\mathrm{H})$ and optimism $(\mathrm{O})$ are predictors of receptive English skills in the general mood category, which makes it the only Emotional Intelligence category which has all sub-categories included in the model. Many psychologists claim that happiness is not merely a positive emotion, but rather 
a skill that can also be developed. Happiness is accepting both pleasant and unpleasant emotions which makes it an important skill in life (Ricard, 2003, cited in MacIntyre et al., 2016). As for optimism, it is the belief that the outcome of a certain effort or a situation will be positive and favorable. Optimism as a mental attitude has been studied by many researchers and second language acquisition experts. They found that happiness and optimism are highly related to motivation, sometimes even referred to as self-motivation (Carver et al., 2010; Hassanzadeh \& Mahdinejad, 2013). These assumptions support the findings that happiness and optimism are the best predictors of receptive English skills when studying the general mood category. In addition, psychologists claim that these sub-categories have many benefits among which is the ability to manage stress (Quick \& Henderson, 2016). However, in this study participants were found to have average stress management skills. When a person is intrinsically motivated, they feel satisfied while performing the task and optimistic about the results.

Although Tunisian IT students have some difficulties in managing their stress, as discussed before, they keep a positive and optimistic attitude which guides and motivates them to move towards their target and believe in positive outcomes as shown in their questionnaire answers. Therefore, even in negative or difficult situations, they are still confident and believe in their capabilities. This can be explained by the fact that they are driven by their self-regulation and ambitions, as well as, their experience with language learning. Regarding this, experts claim that the more languages one knows, the easier it becomes to acquire an additional language. That is to say, multilingual learners have already had the access to at least two linguistic systems. Many studies on the effect of multilingualism showed that they are superior to monolinguals in language learning. Thompson and Khawaja (2016), for example, found that multilingualism has a positive effect in reducing foreign language anxiety. They also deduced that multilingual individuals are more tolerant toward linguistic imperfections; thus, this lowers their affective filters when they are faced with the challenges of learning a new foreign language. Therefore, knowing that their first and second language are completely distinct, it can be said that Tunisian students feel positive and optimistic about learning English as they believe that English linguistic patterns are easier than those of the languages they already speak. 
Ouaja, Widiati, Basthomi, \& Jahbel, Emotional Intelligence and English Skills 245

\section{CONCLUSIONS}

This study examines the relationship between emotional intelligence and English proficiency of Tunisian IT students, as well as, the best predictors of English proficiency among emotional intelligence categories. The overall EI and receptive English skills of the participants were found of average levels. It was also found that the higher the EI of Tunisian IT students was, the higher their receptive English skills were. However, as this study was a preliminary one and the number of the sample was relatively small, involving only Tunisian IT students, the findings of this study could not be generalized to all the population of Tunisian students. Regression analysis revealed the best predictors of receptive English skills as being the interpersonal and stress management categories. The result revealed that Tunisian IT students have high interpersonal and low stress management skills, as well as, average receptive English skills. Through the analysis of the sub-categories, it was also found that, in learning English language, Tunisian IT students were driven and motivated by their goals and ambitions, as well as, their optimism. It was also believed that the linguistic setting and the Tunisian culture highly influence their receptive English skills. However, the fact that their receptive English skills were found to be average could be explained by their weak stress management.

Considering the discussed factors, different recommendations are addressed to English teachers such as the need to be aware of and spread awareness among their students about the importance of EI in English language learning. Moreover, it is recommended that they use materials that include the emotional factors and help students improve their emotional intelligence and apply it in language learning. Furthermore, as students have very limited exposure to English compared to other languages, English teachers need to give more attention and time to, as well as, encourage students with low proficiency in order to help them develop better stress management skills by feeling more at ease. With regard to the limitations of the study, it is recommended that future researchers consider a larger sample in investigating the relationship between EI and receptive English skills, and consider a comprehensive measurement of English proficiency, not only receptive English skills. 
246 TEFLIN Journal, Volume 31, Number 2, July 2020

\section{REFERENCES}

Afshar, H. S., Tofighi, S. \& Hamazavi, R. (2016). Iranian EFL learners' emotional intelligence, learning styles, strategy use, and their L2 achievement. Issues in Educational Research, 26(4), 635-652.

Arfaoui, K. (2017). Living together in Tunisia. Retrieved from https://www.globalpolicyjournal.com/ blog/17/09/2017/living-togethertunisia

Barisonek, E. S. (2005). The relationship between emotional intelligence, academic achievement and academic production among third and sixth grade students. Master's thesis, The State University of New York, New York, USA. Retrieved from ProQuest Dissertations Publishing.

Bar-On, R. (1997a). The Emotional Quotient Inventory (EQ-i): A test of emotional intelligence. Toronto: Multi-Health Systems, Inc.

Bar-On, R. (1997b). The Emotional Quotient Inventory (EQ-i): Technical manual. Multi-Health Systems, Inc.

Bar-On, R., \& Parker, J. D. A. (2000). The handbook of emotional intelligence: Theory, development, assessment, and application at home, school, and in the workplace. Jossey-Bass.

Brackett, M. A., \& Salovey, P. (2004) Measuring emotional intelligence with the Mayer-Salovey-Caruso Emotional Intelligence Test (MSCEIT). In G. Geher (Ed.). Measuring emotional intelligence: Common ground and controversy (pp. 181-196). Nova Science Publishers.

Buchweitz, A., \& Prat, C. (2013). The bilingual brain: Flexibility and control in the human cortex. Physics of Life Reviews, 10(4), 428-443.

Carver, C. S., Scheier, M. F., \& Segerstrom, S. C. (2010). Optimism. Clinical Psychology Review, 30, 879-889.

Chao, C. -T. (2003) Foreign language anxiety and emotional intelligence: A study of EFL students in Taiwan. Texas A \& M University-Kingsville.

Creswell, J. W. (2012) Educational research: Planning, conducting, and evaluating quantitative and qualitative research. Pearson.

Dağl1, M. E. (2006). The relationship between intelligence, adolescent intelligence and academic achievement in adolescence. (Master's Thesis, Mersin University, Mersin, Turkey). Retrieved from https://www.ulusaltezmerkezi.net/ergenlikte-zeka-bolumu-duygusal-zekave-akademik-basari-arasindaki-iliski/ 
Ouaja, Widiati, Basthomi, \& Jahbel, Emotional Intelligence and English Skills 247

Daoud, M. (1991). The processing of EST discourse: Arabic and French native speakers' recognition of rhetorical relationships in engineering texts. $\mathrm{PhD}$ Thesis, University of California, USA.

Daoud, M. (2001). The language situation in Tunisia. Current Issues in Language Planning, 2(1), 1-52.

Dewaele, J. M. (2013). Emotions and language learning. In M. Byram \& A. Hu (Eds.), Routledge encyclopedia of language teaching and learning $\left(2^{\text {nd }} e d\right.$. , pp. 217-220). Routledge.

Dewaele, J. M. (2015). Bilingualism and Multilingualism. In K. Tracy, C. Ilie, $\&$ T. Sandel (Eds.). The international encyclopedia of language and social interaction (pp. 1-11). John Wiley and Sons, Inc.

Dewaele, J. M. (2019). Multilingualism and trait emotional intelligence: An exploratory investigation. International Journal of Multilingualism, 1-15.

Dewaele, J. M., \& Wei, L. (2012). Multilingualism, empathy and multicompetence. International Journal of Multilingualism, 9(4), 352366.

Ebrahimi, M. R., Khoshsima, H., \& Zare-Behtash, E. (2018). The impacts of enhancing emotional intelligence on the development of reading skill. International Journal of Instruction, 11(3), 573-586.

EF Education First. (2019). EF EPI: EF English Proficiency Index: A ranking of 100 countries and regions by English skills. Retrieved from https://www.ef.com/wwen/epi/\#

Elias, M. J. and Arnold, H. (2006). The educator's guide to emotional intelligence and academic achievement: Social-emotional learning in the classroom. Corwin Press.

Evenson, E. A. (2007). Examining the relationship between emotional intelligence and college success. $\mathrm{PhD}$ Thesis, Capella University, Minneapolis, Minnesota, USA. Retrieved from ProQuest Dissertations Publishing.

Eysenck, M. W., Calvo, M. G., Derakshan, N., \& Santos, R. (2007). Anxiety and cognitive performance: Attentional control theory. Emotion, 7(2), 336-353.

Fahim, M., \& Pishghadam, R. (2007) On the role of emotional, psychometric, and verbal intelligences in the academic achievement of university students majoring in English language. Asian EFL Journal, 9(4), 240-253.

Farsian M R, Rezaei N, \& Panahandeh S. (2015). Correlation between achievement motivation, emotional intelligence and the foreign language 
classroom anxiety in French students of Ferdowsi University of Mashhad, IQBQ, 6 (4), 183-200.

Fan, S. P., Keysar, B., Kinzler, K. D., \& Liberman, Z. (2015) The exposure advantage: Early exposure to a multilingual environment promotes effective communication. Journal of Psychological Science, 26(7), 10901097.

Firdaus, M. A. (2017). Looking at the link between emotional intelligence and reading comprehension among senior high school students. Jurnal Pendidikan dan Pengajaran [Journal of Education and Instruction], 4(2), 18-28.

Ghosn, I. (2001). Nurturing emotional intelligence through literature. English Teaching Forum, 39(1).

Goleman, D. (1995). Emotional intelligence: Why it can matter more than IQ. Bantam Books.

Goleman, D. (2006). Emotional intelligence: The 10th anniversary edition. Bantam Books.

Hasanzadeh, R., \& Shahmohamadi, F. (2011) Study of emotional intelligence and learning strategies. Procedia - Social and Behavioral Sciences, 29, 824-1829.

Hassan, N. M. E. (2015). The relationship between emotional intelligence and English language achievements among private secondary schools' students at Khartoum locality. Ahfad Journal, 32(1), 15-29.

Hassanzadeh, R. \& Mahdinejad, G. (2013). Relationship between happiness and achievement motivation: A case of university students. Journal of Elementary Education, 23(1), 53-65.

Karaman, E. (2012). Turkish undergraduate students' emotional intelligence and their performance on English language test. (Master's Thesis, Eastern Mediterranean University, Gazimağusa, North Cyprus). Retrieved from http://hdl.handle.net/11129/300.

Krashen, S. (1981). Second language acquisition and second language learning. Pergamon Press.

Li, C. (2019). A positive psychology perspective on Chinese EFL students' trait emotional intelligence, foreign language enjoyment and EFL learning achievement. Journal of Multilingual and Multicultural Development, 41(3), 246-263.

Lightbown, P. M., \& Spada, N. (2010). How languages are learned. Oxford University Press. 
Ouaja, Widiati, Basthomi, \& Jahbel, Emotional Intelligence and English Skills 249

MacIntyre, P. D., Gregersen, T., \& Mercer, S. (2016). Positive psychology in SLA. Multilingual Matters.

Maslow, A. H. (1943). A theory of human motivation. Psychological Review, $50(4), 370-396$.

Martin, K. (2010). Strategic use of emotional intelligence in organizational settings: Exploring the dark side. Research in Organizational Behavior, 30, 129-152.

Mayer, J. D., Caruso, D. R., \& Salovey, P. (2000). Emotional intelligence as zeitgeist, as personality, and as a mental ability. In R. Bar-On \& J. D. A. Parker. (Eds.). The handbook of emotional intelligence: Theory, development, assessment, and application at home, school, and in workplace (pp. 92-118). Jossey-Bass.

Melliti, M. (2008). The perceived value of English: The case of Tunisian university students. Lambert Academic Publishing.

Motallebzadeh, K. (2009). The relationship between the emotional intelligence of Iranian EFL learners and their reading comprehension and structural ability. Journal of Teaching English as a Foreign Language and Literature, 1(4), 39-55.

Noroozi, H. (2017). The relationship between willingness to communicate, perceptual learning styles and language proficiency of Iranian EFL learners. Master's Thesis, Islamic Azad University, South Tehran Branch, Iran.

Oxford, R. L., Lavine, R. Z., \& Crookall, D. (1989). Language learning strategies, the communicative approach, and their classroom implications. Foreign Language Annals, 22(1), 29-39.

Oz, H., Demirezen, M., \& Pourfeiz, J. (2015). Emotional intelligence and attitudes towards foreign language learning: Pursuit of relevance and implications. Social and Behavioral Sciences, 186 (2015), 416 - 423.

Parker, J. D. A., Hogan, M. J., Majeski, S. A., \& Summerfeldt, L. J. (2004). Emotional intelligence and academic success: Examining the transition from high school to university. Personality and Individual Differences, $36(1), 163-172$.

Pishghadam, R. (2009a). Emotional and verbal intelligences in language learning. Iranian Journal of Language Studies, 3(1), 43-64.

Pishghadam, R. (2009b) A quantitative analysis of the relationship between emotional intelligence and foreign language learning. Electronic Journal of Foreign Language Teaching, 6(1), 31-41. 
Plonsky, L., \& Brown, D. (2015). Domain definition and search techniques in meta-analyses of L2 research (or why 18 meta-analyses of feedback have different results). Second Language Research, 31(2), 267-278.

Quick, J., \& Henderson, D. (2016). Occupational stress: Preventing suffering, enhancing wellbeing. International Journal of Environmental Research and Public Health, 13(5), 459-470.

Rouhani, A. (2008). An investigation into emotional intelligence, foreign language anxiety and empathy through a cognitive-affective course in an EFL context. Linguistik Online, 34(2), 42-57.

Rost, M., \& Candlin, C. N. (2013). Listening in language learning. Routledge

Şakrak, Ş. (2009) The relationship between emotional intelligence and foreign language anxiety in Turkish EFL students. Master's Thesis, Bilkent University, Ankara, Turkey. Retrieved from http://repository. bilkent.edu.tr/handle/11693/15422

Shakib, S., \& Barani, G. (2011). The relationship between emotional intelligence and language proficiency of Iranian high school students. Procedia- Social and Behavioral Sciences, 30, 1603-1607.

Shao, K., Yu, w., \& Ji, Z. (2013). An exploration of Chinese EFL students' emotional intelligence and foreign language anxiety. The Modern Language Journal, 97(4), 917-929.

Sutten, R. E., \& Wheatley, K. F. (2003). Teachers' emotions and teaching: A review of the literature and directions for future research. Educational Psychology Review, 15(4), 327-358.

Thompson, A. S., \& Khawaja, A. J. (2016). Foreign language anxiety in Turkey: The role of multilingualism. Journal of Multilingual and Multicultural Development, 37(2), 115-130.

Walker, M. E. B. (2006). Emotional intelligence and academic success in college. (PhD Thesis, University of Southern Mississippi, Hattiesburg, Mississippi, USA). Retrived from http://www.proquest.com/enUS/products/dissertations/individuals.shtml

Yerli, S. (2009) The correlation between anxiety and emotional intelligence in foreign language learning. Master's Thesis, Gazi University, Ankara, Turkey. Retrieved from https://dspace.gazi.edu.tr/handle/ 20.500.12602/190020

Yllmaz, S. (2007). The relationship between Emotional Intelligence and academic success. (Master's Thesis, Atatürk University, Erzurum, 
Ouaja, Widiati, Basthomi, \& Jahbel, Emotional Intelligence and English Skills 251

Turkey). Retrived from https://atauni.edu.tr/yuklemeler/a9a64845 c9826532e647dc76762a85c6.pdf

Yu, W., Shao, K., \& Xiang, Y. (2015). The relationships among Chinese EFL learners' emotional intelligence, foreign language anxiety and english proficiency. Modern Foreign Languages, 5, 656-666.

Zarafshan, M., \& Ardeshiri, M. (2012). The relationship between emotional intelligence, language learning strategies and English proficiency among Iranian EFL university students. Journal of Educational and Instructional Studies in the World, 2(3), 105-114. 


\section{APPENDIX: BAR-ON EQ-I}

Using the alternatives (A, B, C, D, and E) below, decide how much you " agree" or "disagree" with each statement and mark your choices on the optical answer sheet.

En utilisant les alternatives ( $A, B, C, D$ et $E$ ) ci-dessous, décidez combien vous êtes "d'accord "ou" pas d'accord "avec chaque affirmation et marquez vos choix sur la feuille de réponses.

A) Strongly Agree $=5$

Fortement d'accord $=5$

B) Agree $=4$

D'accord $=4$

C) Undecided $=3$

Indécis $=3$

D) Disagree $=2$

Pas d'accord $=2$

E) Strongly Disagree $=1$

Fortement en désaccord $=1$

\begin{tabular}{|c|c|c|c|c|c|}
\hline $\begin{array}{l}\text { Statements } \\
\text { Déclarations }\end{array}$ & $\mathbf{A}$ & B & $\mathbf{C}$ & D & $\mathbf{E}$ \\
\hline $\begin{array}{l}\text { 1. My strategy to deal with difficulties is going step by } \\
\text { step. } \\
\text { Ma stratégie pour faire face aux difficultés va pas à pas. }\end{array}$ & 5 & 4 & 3 & 2 & 1 \\
\hline $\begin{array}{l}\text { 2. It is easy for me to show my emotions. } \\
\text { Cest facile de montrer mes émotions. }\end{array}$ & 5 & 4 & 3 & 2 & 1 \\
\hline $\begin{array}{l}\text { 3. I cannot stand too much stress. } \\
\text { Je ne supporte pas trop de stress. }\end{array}$ & 5 & 4 & 3 & 2 & 1 \\
\hline $\begin{array}{l}\text { 4. I can easily stop daydreaming and connect to reality. } \\
\text { Je peux facilement arrêter de rêver et me connecter à la } \\
\text { réalité. }\end{array}$ & 5 & 4 & 3 & 2 & 1 \\
\hline $\begin{array}{l}\text { 5. Although there are some problems from time to time, } \\
\text { I usually believe that everything is going to be fine. } \\
\text { Bien qu'il y ait des problèmes de temps en temps, je pense } \\
\text { généralement que tout va bien se passer. }\end{array}$ & 5 & 4 & 3 & 2 & 1 \\
\hline
\end{tabular}


Ouaja, Widiati, Basthomi, \& Jahbel, Emotional Intelligence and English Skills 253

\begin{tabular}{|l|l|l|l|l|l|}
\hline \multicolumn{1}{|c|}{$\begin{array}{l}\text { Statements } \\
\text { Déclarations }\end{array}$} & A & B & C & D & E \\
\hline $\begin{array}{l}\text { 6. It is hard for me to encounter unpleasant events. } \\
\text { Il m'est difficile de faire face à des événements } \\
\text { désagréables. }\end{array}$ & 5 & 4 & 3 & 2 & 1 \\
\hline $\begin{array}{l}\text { 7. I can tell someone that I do not agree with him/her. } \\
\text { Je peux dire à quelqu'un que je ne suis pas d'accord avec } \\
\text { lui. }\end{array}$ & 5 & 4 & 3 & 2 & 1 \\
\hline $\begin{array}{l}\text { 8. When I feel sad, I know what causes these feelings. } \\
\text { Quand je suis triste, je sais ce qui cause ces sentiments. }\end{array}$ & 5 & 4 & 3 & 2 & 1 \\
\hline $\begin{array}{l}\text { 9. Others think that I am unpretentious } \\
\text { Les autres pensent que je suis sans prétention }\end{array}$ & 5 & 4 & 3 & 2 & 1 \\
\hline $\begin{array}{l}\text { 10. Most of the time I am sure of myself. } \\
\text { La plupart du temps, je suis sûr de moi. }\end{array}$ & 5 & 4 & 3 & 2 & 1 \\
\hline $\begin{array}{l}\text { 11. I am a peevish person. } \\
\text { Je suis une personne faible. }\end{array}$ & 5 & 4 & 3 & 2 & 1 \\
\hline $\begin{array}{l}\text { 12. I am not aware of the things around me. } \\
\text { Je ne suis pas conscient des choses autour de moi. }\end{array}$ & 5 & 4 & 3 & 2 & 1 \\
\hline $\begin{array}{l}\text { 13. I cannot easily share my inner feelings with others. } \\
\text { Je ne peux pas facilement partager mes sentiments avec les } \\
\text { autres. }\end{array}$ & 5 & 4 & 3 & 2 & 1 \\
\hline $\begin{array}{l}\text { 14. When I consider my good and bad habits, I feel } \\
\text { happy. Quand je considère mes bonnes et mes mauvaises } \\
\text { habitudes, je me sens heureuse. }\end{array}$ & 5 & 4 & 3 & 2 & 1 \\
\hline $\begin{array}{l}\text { 15. I try to make my life meaningful. } \\
\text { J'essaie de donner un sens à ma vie. }\end{array}$ & 5 & 4 & 3 & 2 & 1 \\
\hline $\begin{array}{l}\text { 16. I cannot express my love. } \\
\text { Je ne peux pas exprimer mon amour. }\end{array}$ & 5 & 3 & 2 & 1 \\
\hline $\begin{array}{l}\text { 17. I do not exactly know the things I am good at. } \\
\text { Je ne connais pas exactement les domaines dans lesquels je } \\
\text { suis bon. }\end{array}$ & 5 & 4 & 3 & 2 & 1 \\
\hline $\begin{array}{l}\text { 18. I can quit my old habits. } \\
\text { Je peux quitter mes vieilles habitudes. }\end{array}$ & 5 & 4 & 3 & 2 & 1 \\
\hline $\begin{array}{l}\text { 19. I try to learn the things I like as much as I can. } \\
\text { J'essaie d'apprendre les choses que j'aime autant que je } \\
\text { peux. }\end{array}$ & 5 & 4 & 3 & 2 & 1 \\
\hline
\end{tabular}




\begin{tabular}{|l|l|l|l|l|l|}
\hline \multicolumn{1}{|c|}{$\begin{array}{c}\text { Statements } \\
\text { Déclarations }\end{array}$} & A & B & C & D & E \\
\hline $\begin{array}{l}\text { 20. I can tell people when I get angry with them. } \\
\text { Je peux dire aux gens quand je suis en colère contre eux. }\end{array}$ & 5 & 4 & 3 & 2 & 1 \\
\hline $\begin{array}{l}\text { 21. I am not sure about what I would like to do in life. } \\
\text { Je ne suis pas sûr de ce que j'aimerais faire dans la vie. }\end{array}$ & 5 & 4 & 3 & 2 & 1 \\
\hline $\begin{array}{l}\text { 22. I prefer to work at a place where I am often } \\
\text { reminded of my responsibilities. } \\
\text { Je préfère travailler dans un endroit où on me rappelle } \\
\text { souvent mes responsabilités. }\end{array}$ & 5 & 4 & 3 & 2 & 1 \\
\hline $\begin{array}{l}\text { 23. When I am solving a problem, I search every } \\
\text { possibility, and then decide on the best one. } \\
\text { Quand je résous un problème, je cherche toutes les } \\
\text { possibilités, puis je choisis la meilleure. }\end{array}$ & 5 & 4 & 3 & 2 & 1 \\
\hline $\begin{array}{l}\text { 24. I am a follower rather than a leader. } \\
\text { Je suis un disciple plutôt qu'un leader. }\end{array}$ & 5 & 4 & 3 & 2 & 1 \\
\hline $\begin{array}{l}\text { 25. Although people do not directly express their } \\
\text { feelings, I can understand them very well. } \\
\text { Bien que les gens n'expriment pas directement leurs } \\
\text { sentiments, je peux très bien les comprendre. }\end{array}$ & 5 & 4 & 3 & 2 & 1 \\
\hline $\begin{array}{l}\text { 26. I am happy with my physical appearance. } \\
\text { Je suis content de mon apparence physique. }\end{array}$ & 5 & 4 & 3 & 2 & 1 \\
\hline $\begin{array}{l}\text { 27. I can easily share my ideas with people. } \\
\text { Je peux facilement partager mes idées avec les gens. }\end{array}$ & 5 & 4 & 3 & 2 & 1 \\
\hline $\begin{array}{l}\text { 28. I like doing things that appeal to me. } \\
\text { J'aime faire des choses qui me plaisent. }\end{array}$ & 5 & 4 & 3 & 2 & 1 \\
\hline $\begin{array}{l}\text { 29. I am an impatient person. } \\
\text { Je suis une personne impatiente. }\end{array}$ & 5 & 4 & 3 & 2 & 1 \\
\hline $\begin{array}{l}\text { 30. I take care of not hurting other people's feelings. } \\
\text { Je veuille à ne pas blesser les sentiments des autres. }\end{array}$ & 5 & 4 & 3 & 2 & 1 \\
\hline $\begin{array}{l}\text { 31. Even though the things get complicated, I have } \\
\text { motivation to keep on. } \\
\text { Même si les choses se compliquent, j'ai la motivation pour } \\
\text { continuer. }\end{array}$ & 5 & 3 & 2 & 1 \\
\hline $\begin{array}{l}\text { 32. I have good relations with others. } \\
\text { J'ai de bonnes relations avec les autres. }\end{array}$ & 4 & 3 & 2 & 1 \\
\hline
\end{tabular}


Ouaja, Widiati, Basthomi, \& Jahbel, Emotional Intelligence and English Skills 255

\begin{tabular}{|l|l|l|l|l|l|}
\hline \multicolumn{1}{|c|}{$\begin{array}{c}\text { Statements } \\
\text { Déclarations }\end{array}$} & A & B & C & D & E \\
\hline $\begin{array}{l}\text { 33. When I encounter an unpleasant situation, I would } \\
\text { like to collect information as much as I can. } \\
\begin{array}{l}\text { Lorsque je rencontre une situation désagréable, je souhaite } \\
\text { collecter autant d'informations que possible. }\end{array}\end{array}$ & 5 & 4 & 3 & 2 & 1 \\
\hline $\begin{array}{l}\text { 34. I enjoy helping people. } \\
\text { J'aime aider les gens. }\end{array}$ & 5 & 4 & 3 & 2 & 1 \\
\hline $\begin{array}{l}\text { 35. I have achieved just a few things in the last couple of } \\
\text { years. } \\
\text { J'ai achevé peu de choses au cours des deux dernières } \\
\text { années. }\end{array}$ & 5 & 4 & 3 & 2 & 1 \\
\hline $\begin{array}{l}\text { 36. It is hard to control my rage. } \\
\text { Il est difficile de contrôler ma colère. }\end{array}$ & 5 & 4 & 3 & 2 & 1 \\
\hline $\begin{array}{l}\text { 37. I do not enjoy my life. } \\
\text { Je ne profite pas de ma vie. }\end{array}$ & 5 & 4 & 3 & 2 & 1 \\
\hline $\begin{array}{l}\text { 38. It is hard to define my emotions. } \\
\text { Il est difficile de définir mes émotions. }\end{array}$ & 5 & 4 & 3 & 2 & 1 \\
\hline $\begin{array}{l}\text { 39. I cannot protect my rights. } \\
\text { Je ne peux pas protéger mes droits. }\end{array}$ & 5 & 4 & 3 & 2 & 1 \\
\hline $\begin{array}{l}\text { 40. I am a very joyful person. } \\
\text { Je suis une personne très joyeuse. }\end{array}$ & 5 & 4 & 3 & 2 & 1 \\
\hline $\begin{array}{l}\text { 41. My acts without thinking cause problems. } \\
\text { Mes actes sans penser causent des problèmes. }\end{array}$ & 5 & 4 & 3 & 2 & 1 \\
\hline $\begin{array}{l}\text { 42. People think that I am a social person. } \\
\text { Les gens pensent que je suis une personne sociale. }\end{array}$ & 5 & 4 & 3 & 2 & 1 \\
\hline $\begin{array}{l}\text { 43. It is crucial to be a citizen who obeys the rules. } \\
\text { Il est essentiel d'être un citoyen qui respecte les règles. }\end{array}$ & 5 & 4 & 3 & 2 & 1 \\
\hline $\begin{array}{l}\text { 44. I find it difficult to accept myself as I am. } \\
\text { J'ai du mal à m'accepter tel que je suis. }\end{array}$ & 5 & 4 & 3 & 2 & 1 \\
\hline $\begin{array}{l}\text { 45. Even If I had to be somewhere else I would help a } \\
\text { crying child to find his/ her parents. } \\
\text { Même si je devais être ailleurs, j'aiderais un enfant qui } \\
\text { pleure à retrouver ses parents. }\end{array}$ & 5 & 4 & 3 & 2 & 1 \\
\hline $\begin{array}{l}\text { 46. My friends can share their special things with me. } \\
\text { Mes amis peuvent partager leurs choses spéciales avec moi. }\end{array}$ & 5 & & \\
\hline
\end{tabular}


256 TEFLIN Journal, Volume 31, Number 2, July 2020

\begin{tabular}{|c|c|c|c|c|c|}
\hline $\begin{array}{c}\text { Statements } \\
\text { Déclarations }\end{array}$ & $\mathbf{A}$ & B & C & D & $\mathbf{E}$ \\
\hline $\begin{array}{l}\text { 47. I can't decide on my own. } \\
\text { Je ne peux pas décider par moi-même. }\end{array}$ & 5 & 4 & 3 & 2 & 1 \\
\hline $\begin{array}{l}\text { 48. I respect other people. } \\
\text { Je respecte les autres. }\end{array}$ & 5 & 4 & 3 & 2 & 1 \\
\hline $\begin{array}{l}\text { 49. I care what happens to other people. } \\
\text { Je me soucie de ce qui arrive aux autres. }\end{array}$ & 5 & 4 & 3 & 2 & 1 \\
\hline $\begin{array}{l}\text { 50. It is difficult for me to change my opinion about } \\
\text { some things. } \\
\text { Il m'est difficile de changer d'avis sur certaines choses. }\end{array}$ & 5 & 4 & 3 & 2 & 1 \\
\hline $\begin{array}{l}\text { 51. I am generally stuck when I try to find different } \\
\text { solutions to problems. } \\
\text { Je suis généralement bloqué lorsque j'essaie de trouver } \\
\text { différentes solutions aux problèmes. }\end{array}$ & 5 & 4 & 3 & 2 & 1 \\
\hline $\begin{array}{l}\text { 52. I try to see everything as it is without fantasies and } \\
\text { dreaming. } \\
\text { J'essaie de tout voir tel qu'il est sans fantasmes ni rêves. }\end{array}$ & 5 & 4 & 3 & 2 & 1 \\
\hline $\begin{array}{l}\text { 53. I know what I feel. } \\
\text { Je sais ce que je ressens. }\end{array}$ & 5 & 4 & 3 & 2 & 1 \\
\hline $\begin{array}{l}\text { 54. It is fun to be with me. } \\
\text { C'est amusant d'être avec moi. }\end{array}$ & 5 & 4 & 3 & 2 & 1 \\
\hline $\begin{array}{l}\text { 55. I like the type of my personality. } \\
\text { J'aime le type de ma personnalité. }\end{array}$ & 5 & 4 & 3 & 2 & 1 \\
\hline $\begin{array}{l}\text { 56. I indulged in my dreams and fantasies. } \\
\text { Je me suis livré à mes rêves et fantasmes. }\end{array}$ & 5 & 4 & 3 & 2 & 1 \\
\hline $\begin{array}{l}\text { 57. My close relationships are very important for me and } \\
\text { my friends. } \\
\text { Mes relations intimes sont très importantes pour moi et mes } \\
\text { amis. }\end{array}$ & 5 & 4 & 3 & 2 & 1 \\
\hline $\begin{array}{l}\text { 58. It is difficult for me to start new things. } \\
\text { Il m'est difficile de commencer de nouvelles choses. }\end{array}$ & 5 & 4 & 3 & 2 & 1 \\
\hline $\begin{array}{l}\text { 59. If I had to I would break the law. } \\
\text { Si je devais le faire, je violerais la loi. }\end{array}$ & 5 & 4 & 3 & 2 & 1 \\
\hline $\begin{array}{l}\text { 60. I am worried. } \\
\text { Je suis inquiet. }\end{array}$ & 5 & 4 & 3 & 2 & 1 \\
\hline
\end{tabular}


Ouaja, Widiati, Basthomi, \& Jahbel, Emotional Intelligence and English Skills 257

\begin{tabular}{|l|l|l|l|l|l|}
\hline \multicolumn{1}{|c|}{$\begin{array}{l}\text { Statements } \\
\text { Déclarations }\end{array}$} & A & B & C & D & E \\
\hline $\begin{array}{l}\text { 61. It is easy for me to adapt myself to new conditions. } \\
\text { Il m'est facile de m'adapter aux nouvelles conditions. }\end{array}$ & 5 & 4 & 3 & 2 & 1 \\
\hline $\begin{array}{l}\text { 62. I can easily make friends. } \\
\text { Je peux facilement me faire des amis. }\end{array}$ & 5 & 4 & 3 & 2 & 1 \\
\hline $\begin{array}{l}\text { 63. I know how to cope with annoying problems. } \\
\text { Je sais comment faire face à des problèmes ennuyeux. }\end{array}$ & 5 & 4 & 3 & 2 & 1 \\
\hline $\begin{array}{l}\text { 64. When I work with others, I trust their ideas more } \\
\text { than mine. Lorsque je travaille avec d'autres personnes, je } \\
\text { fais plus confiance à leurs idées qu'aux miennes. }\end{array}$ & 5 & 4 & 3 & 2 & 1 \\
\hline $\begin{array}{l}\text { 65. I feel bad too often. } \\
\text { Je me sens mal trop souvent. }\end{array}$ & 5 & 4 & 3 & 2 & 1 \\
\hline $\begin{array}{l}\text { 66. I don't stop easily when I start to speak. } \\
\text { Je ne m'arrête pas facilement quand je commence à parler. }\end{array}$ & 5 & 4 & 3 & 2 & 1 \\
\hline $\begin{array}{l}\text { 67. I don't get on well with people around. } \\
\text { Je ne m'entends pas bien avec les gens. }\end{array}$ & 5 & 4 & 3 & 2 & 1 \\
\hline $\begin{array}{l}\text { 68. I know how to keep calm under difficult } \\
\text { circumstances. } \\
\text { Je sais rester calme dans des conditions difficiles. }\end{array}$ & 5 & 4 & 3 & 2 & 1 \\
\hline $\begin{array}{l}\text { 69. I appreciate myself. } \\
\text { Je m'apprécie. }\end{array}$ & 5 & 4 & 3 & 2 & 1 \\
\hline $\begin{array}{l}\text { 70. I am told to lower my voice while having an } \\
\text { argument. } \\
\text { On me dit de baisser la voix lorsque je me dispute. }\end{array}$ & 5 & 4 & 3 & 2 & 1 \\
\hline $\begin{array}{l}\text { 71. I can't change my style easily. } \\
\text { Je ne peux pas changer de style facilement. }\end{array}$ & 5 & 4 & 3 & 2 & 4 \\
\hline $\begin{array}{l}\text { 72. I am happy with my life. } \\
\text { Je suis heureux de ma vie. }\end{array}$ & 5 & 4 & 3 & 2 & 1 \\
\hline $\begin{array}{l}\text { 73. I need people more than people need me. } \\
\text { J'ai besoin de plus de personnes que de personnes. }\end{array}$ & 5 & 4 & 3 & 2 & 1 \\
\hline $\begin{array}{l}\text { 74. I love weekends and holidays. } \\
\text { J'aime les week-ends et les vacances }\end{array}$ & 2 & 1 \\
\hline $\begin{array}{l}\text { 75. I can cope with stress without getting annoyed. } \\
\text { Je peux faire face au stress sans me fâcher. }\end{array}$ & 5 & 1 \\
\hline
\end{tabular}


258 TEFLIN Journal, Volume 31, Number 2, July 2020

\begin{tabular}{|c|c|c|c|c|c|}
\hline $\begin{array}{l}\text { Statements } \\
\text { Déclarations }\end{array}$ & $\mathbf{A}$ & B & $\mathbf{C}$ & D & $\mathbf{E}$ \\
\hline $\begin{array}{l}\text { 76. I believe that I will overcome very hard situations. } \\
\text { Je crois que je vais surmonter des situations très difficiles. }\end{array}$ & 5 & 4 & 3 & 2 & 1 \\
\hline $\begin{array}{l}\text { 77. I don't notice suffering people. } \\
\text { Je ne remarque pas les personnes qui souffrent. }\end{array}$ & 5 & 4 & 3 & 2 & 1 \\
\hline $\begin{array}{l}\text { 78. I usually hope for the best. } \\
\text { J'espère habituellement que tout ira pour le mieux. }\end{array}$ & 5 & 4 & 3 & 2 & 1 \\
\hline $\begin{array}{l}\text { 79. It is hard for other people to trust me. } \\
\text { Il est difficile pour les autres de me faire confiance. }\end{array}$ & 5 & 4 & 3 & 2 & 1 \\
\hline $\begin{array}{l}\text { 80. I know that it is difficult to control my anxiety. } \\
\text { Je sais qu'il est difficile de contrôler mon anxiété. }\end{array}$ & 5 & 4 & 3 & 2 & 1 \\
\hline $\begin{array}{l}\text { 81. I easily notice the emotional needs of others. } \\
\text { Je remarque facilement les besoins émotionnels des autres. }\end{array}$ & 5 & 4 & 3 & 2 & 1 \\
\hline $\begin{array}{l}\text { 82. I love exaggerating. } \\
\text { J'aime exagérer. }\end{array}$ & 5 & 4 & 3 & 2 & 1 \\
\hline $\begin{array}{l}\text { 83. I find it hard to smile. } \\
J^{\prime} \text { ai du mal à sourire. }\end{array}$ & 5 & 4 & 3 & 2 & 1 \\
\hline $\begin{array}{l}\text { 84. I face my negative feelings and look through them at } \\
\text { the proper time. } \\
\text { Je fais face à mes sentiments négatifs et je les regarde au } \\
\text { bon moment. }\end{array}$ & 5 & 4 & 3 & 2 & 1 \\
\hline $\begin{array}{l}\text { 85. I usually feel that I will fail before I start doing new } \\
\text { things. J'ai généralement le sentiment d'échouer avant de } \\
\text { commencer à faire de nouvelles choses. }\end{array}$ & 5 & 4 & 3 & 2 & 1 \\
\hline $\begin{array}{l}\text { 86. I find it hard to say "no" when I don't want to do } \\
\text { anything. } \\
\text { J'ai du mal à dire «non» quand je ne veux rien faire. }\end{array}$ & 5 & 4 & 3 & 2 & 1 \\
\hline $\begin{array}{l}\text { 87. The first thing I do is to think when I face a problem. } \\
\text { La première chose que je fais est de penser lorsque je suis } \\
\text { confronté à un problème. }\end{array}$ & 5 & 4 & 3 & 2 & 1 \\
\hline $\begin{array}{l}\text { 88. I sincerely decided how much I agreed or disagreed } \\
\text { with each of the above statements. } \\
\text { J'ai sincèrement décidé combien j'étais d'accord ou en } \\
\text { désaccord avec chacune des déclarations ci-dessus. }\end{array}$ & 5 & 4 & 3 & 2 & 1 \\
\hline
\end{tabular}

